Biletska Y., Plotnikova R.

\title{
RESEARCH OF THE PHYTOESTROGENS CONTENT IN SOYBEAN AND CHICKPEA FLOUR
}

Об’єктом дослідження є сорт нуту «Краснокутський 195», сорт сої «Алмаз», врожаїв 2018 р. колекиійного розсадника «Агротек» (м. Київ, Україна). Одним з найбільш проблемних місчь є неоднозначне ставленням багатьох вчених відносно якісного та кількісного вмісту фітоекстрогенів у зернах бобових. В ході дослідження використовувався метод диференціальної спектрофотометрії. Встановлено, що нативне зерно сої та нуту є носіями 36,8 та 22,3 \% фітоексторогенів. Під час пророщення, сушіння та помелу зерен бобових вміст фітоестрогенів знижується до 15,6 \% у борошні сої та до 13,3\% у борошні нуту. Використання KI, як середовища для пророщення зерна сої, та $\mathrm{NaHSeO}_{3}$, як середовища для пророщення зерна нута, знижує вміст фітоестрогенів на 2,7 та 1,6\%, відповідно. Визначено, що усі дослідні зразки мають пік поглинання при $\lambda=400$ Нм, що відповідає вмісту в них ізофлавоноїду даїдзеїну. Зразки борошна із пророщеного зерна сої та нуту у розчинах мінеральних солей мають пік поглинання при $\lambda=225$ Нм, що відповідає вмісту в них ізофлавоноїду даїдзину. Встановлено, що пророщення зерен бобових у розчинах мінеральних солей не впливає на вміст біоханіну та формононетину. У зразках із борошном нуту, пророщеного у розчині $\mathrm{NaHSeO}$, спостерігаються збільшення вмісту геністеїну на $60 \%$ відносно контролю. Проведений комплекс досліджень дає підстави стверджувати, що постає необхідність вивчення впливу борошна сої та нуту, пророщених у розчинах $\mathrm{KI}$ та $\mathrm{NaHSeO}$, відповідно, на біологічних об'єктах.

Отримані у дослідженні результати є науковим підгрунтям для корекції раціонів харчування осіб, які мають ендокринні порушення і потребують спеціального дієтичного харчування.

Ключові слова: раціони харчування, спеціальне дієтичне харчування, вміст фітоекстрогенів, борошно сої, борошно нуту.

\section{Introduction}

Currently, scientists around the world are actively discussing, possibly, the toxic effects of soybean and chickpeas in post-puberty and pregnancy due to the content of phytoestrogens in their composition. At the same time, they are necessary for people of reproductive age and during menopause [1]. Phytoestrogens are a group of non-steroidal, plant-derived substances which molecular weight is similar to the molecular structure of estrogen. They belong to the class of flavonoids contained in plant products, and soybean and chickpeas are leaders in its content [2]. Phytoestrogens are in the composition of chickpea and soybean in significant quantities, from 18 to $562 \mathrm{mg} / 100 \mathrm{~g}$ [3]. During the study of the structure and biological effect of phytoestrogen, two main groups of active substances are isolated - isoflavonoids and lignans [4]. Isoflavonoids are divided into daidzein, daidzin, formononetin, genistein, biohanin. The greatest attention of scientists studying the effect of soybean and chickpea on endocrine states is devoted to the study of isoflavonoids [5]. The relevance of the studies is associated with the ambiguous attitude of many scientists about the dangers and benefits of leguminous phytoestrogens/isoflavonoids [6]. The products of the processing of leguminous grains, such as germinated grain and flour from it, have not been studied at all. Let's consider it relevant to conduct this research complex, where the object of research is the Krasnokutsky 195 chickpea variety, the Almaz soybean variety, and the 2018 harvest from the Agrotek collection nursery (Kyiv, Ukraine). The aim of research is studying the content of phytoestrogens and isoflavonoids in grains and flour of soybean and chickpea.

\section{Methods of research}

The study of the total content of phytoestrogens in native grain and soybean and chickpea flour is determined by the method of differential spectrophotometry [7]. The dependence of the change in isoflavonoids of soybean and chickpea flour, made by different technologies, is carried out by spectrophotometry using a Lambda $35 \mathrm{UV} / \mathrm{VIS}$ spectrophotometer (USA). The method used is based on the complexation reaction of isoflavonoids, which results in a shift of the absorption band, according to the peak of which it is possible to classify the content (presence) of the investigated isoflavonoids.

\section{Research results and discussion}

The study of the total content of phytoestrogens in native grain and flour of soybean and chickpea obtained by different technologies is shown in Table 1. 
Table 1

The total content of phytoestrogens in native grain and soybean and chickpea flour

\begin{tabular}{|c|l|c|}
\hline No. & \multicolumn{1}{|c|}{ Sample } & $\begin{array}{c}\text { The total content of } \\
\text { phytaestrogens, \% }\end{array}$ \\
\hline 1 & Native soybean grain & $36.8 \pm 0.5$ \\
\hline 2 & Native chickpea grain & $22.3 \pm 04$ \\
\hline 3 & $\begin{array}{l}\text { Control, soybean flour from grains ger- } \\
\text { minated in an aqueous solution }\end{array}$ & $15.6 \pm 0.5$ \\
\hline 4 & $\begin{array}{l}\text { Experience, soybean flour from grains } \\
\text { germinated in a KI solution }\end{array}$ & $13.3 \pm 0.5$ \\
\hline 5 & $\begin{array}{l}\text { Control, chickpea flour from grains ger- } \\
\text { minated in an aqueous solution }\end{array}$ & $12.9 \pm 0.5$ \\
\hline 6 & $\begin{array}{l}\text { Experience, chickpea flour from grains } \\
\text { germinated in a NaHSe0 } 3 \text { solution }\end{array}$ & $11.3 \pm 0.5$ \\
\hline
\end{tabular}

It is established that native soybean and chickpea grains are carriers of 36.8 and $22.3 \%$ phytoestrogens. During germination, drying and grinding of legumes, the content of phytoestrogens decreases to $15.6 \%$ in soybean flour and $13.3 \%$ in chickpea flour. It is established that the use of $\mathrm{KI}$ as a medium for germinating soybean grains and $\mathrm{NaHSeO}_{3}$ as a medium for germinating chickpea grains reduces the content of phytoestrogens by 2.7 and $1.6 \%$, respectively.

The dependence of the change in the isoflavonoids of legumes made using different technologies is shown in Fig. 1.

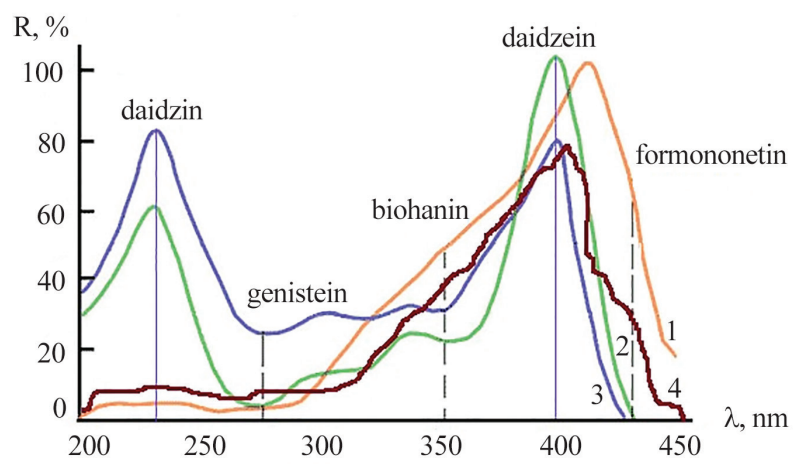

Fig. 1. Dependence of the change in the isoflavonoids of legumes made using different technologies: 1 - control, soybean flour from grains germinated in an aqueous solution; 2 - soybean flour from grains germinated in a KI solution; 3 - chickpea flour from grains germinated in a $\mathrm{NaHSeO}_{3}$ solution; 4 - control, chickpea flour from grains germinated in an aqueous solution

It is established that all the experimental samples have an absorption peak at $\lambda=400 \mathrm{~nm}$, which corresponds to the content of daidzein isoflavonoids in them. Samples of flour from germinated soybean and chickpea grains in solutions of mineral salts have an absorption peak at $\lambda=225 \mathrm{~nm}$, which corresponds to the content of daidzin isoflavonoids in them. This exceeds the samples of soybean flour and chickpea, which are $80 \%$ sprouted in aqueous solutions. Daidzin belongs to the bioisoflavonoid contained in the food products of schoolchildren [8]. The possibility of using daidzin as a substance that can be used against cancer and obesity is non-toxic in [9].

According to the content of isoflavonoids, biohanin and formononetin in all experimental samples without sig- nificant changes, it is obvious that the germination of legume grains in solutions of mineral salts does not affect the content of the above isoflavonoids.

In the sample of chickpea flour germinated in a $\mathrm{NaHSeO}_{3}$ solution, an increase in the genistein content by $60 \%$ is observed, the absorption peak at $\lambda=275 \mathrm{~nm}$. Genistein is not a hormonal stimulant [10]. However, the uncontrolled interaction of genistein with inorganic compounds is described in [11]. And it is also established that these substances can form a bond, which prevents their winter digestibility. There are not a sufficient number of studies on the effect of genistein on the hormonal background in humans, but the results of in vitro studies in mice indicate its safe effect on biological objects [12].

\section{Conclusions}

It is found that native soybean and chickpea grains are carriers of 36.8 and $22.3 \%$ phytoestrogens. During germination, drying and grinding of legumes, the content of phytoestrogens decreases to $15.6 \%$ in soybean flour and $13.3 \%$ in chickpea flour. The use of KI as a medium for germinating soybean grains, and $\mathrm{NaHSeO}_{3}$ as a medium for germinating chickpea grains, reduces the content of phytoestrogens by 2.7 and $1.6 \%$, respectively.

When determining the content of isoflavonoids, it is found that all the experimental samples have an absorption peak at $\lambda=400 \mathrm{~nm}$, which corresponds to the content of isoflavonoids in daidzein. Samples of flour from germinated soybean and chickpea grains in solutions of mineral salts have an absorption peak at $\lambda=225 \mathrm{~nm}$, which corresponds to the content of isoflavonoids in daidzin. It is established that the germination of legumes in solutions of mineral salts does not affect the content of biohanin and formononetin. In samples with chickpea flour sprouted in a $\mathrm{NaHSeO}_{3}$ solution, an increase in genistein content by $60 \%$ relative to the control is observed.

The research results will be useful for merchandisers and technologists of the food industry, working on the development of culinary dishes and diets for people with special dietary nutrition.

\section{References}

1. Shubina, G. (2008). Mirovoi rynok bobovikh i produktov ikh pererabotki. Miasnoi biznes, 7 (69), 32-36.

2. UK-Committee-on-Toxicity (2003). Phytoestrogens and health. Committee on Toxicity of Chemicals in Food, Consumer Products and the Environment. London. Available at: https:// cot.food.gov.uk/sites/default/files/cot/phytoreport0503.pdf

3. Allred, C. D., Twaddle, N. C., Allred, K. F., Goeppinger, T. S., Churchwell, M. I., Ju, Y. H. et. al. (2005). Soy Processing Affects Metabolism and Disposition of Dietary Isoflavones in Ovariectomized Balb/c Mice. Journal of Agricultural and Food Chemistry, 53 (22), 8542-8550. doi: http://doi.org/10.1021/ jf051246w

4. Hosoda, K., Furuta, T., Yokokawa, A., Ogura, K., Hiratsuka, A., Ishii, K. (2008). Plasma Profiling of Intact Isoflavone Metabolites by High-Performance Liquid Chromatography and Mass Spectrometric Identification of Flavone Glycosides Daidzin and Genistin in Human Plasma after Administration of Kinako. Drug Metabolism and Disposition, 36 (8), 1485-1495. doi: http:// doi.org/10.1124/dmd.108.021006

5. Steensma, A., Faassen-Peters, M. A. W., Noteborn, H. P. J. M., Rietjens, I. M. C. M. (2006). Bioavailability of Genistein and Its Glycoside Genistin As Measured in the Portal Vein of Freely Moving Unanesthetized Rats. Journal of Agricultural and Food Chemistry, 54 (21), 8006-8012. doi: http://doi.org/ 10.1021/jf060783t 
6. Xu, X., Wang, H.-J., Murphy, P. A., Hendrich, S. (2000). Neither Background Diet Nor Type of Soy Food Affects Short-Term Isoflavone Bioavailability in Women. The Journal of Nutrition, 130 (4), 798-801. doi: http://doi.org/10.1093/jn/130.4.798

7. Lysenko, H. P. (2017). Metodom vyznachennia fitoestroheniv v boroshni bobovykh. Visnyk ahrarnoi nauky, 1, 72-75.

8. Bhagwat, S. A., Haytowitz, D. B., Holden, J. M. (2008). Update of the USDA's database for the isoflavone content in selected foods. Food, Nutrition, Physical Activity and the Prevention of Cancer: Global Perspective. Washington.

9. Setchell, K. D., Zimmer-Nechemias, L., Cai, J., Heubi, J. E. (1998). Isoflavone content of infant formulas and the metabolic fate of these phytoestrogens in early life. The American Journal of Clinical Nutrition, 68 (6), 1453S-1461S. doi: http://doi.org/ 10.1093/ajcn/68.6.1453s

10. Hoey, L., Rowland, I. R., Lloyd, A. S., Clarke, D. B., Wiseman, H. (2004). Influence of soya-based infant formula consumption on isoflavone and gut microflora metabolite concentrations in urine and on faecal microflora composition and metabolic activity in infants and children. British Journal of Nutrition, 91 (4), 607-616. doi: http://doi.org/10.1079/bjn20031083
11. Farnsworth, N. R., Bingel, A. S., Cordell, G. A., Crane, F. A., Fong, H. H. S. (1975). Potential Value of Plants As Sources of New Antifertility Agents I. Journal of Pharmaceutical Sciences, 64 (4), 535-598. doi: http://doi.org/10.1002/jps.2600640404

12. Dugoua, J. J., Seely, D., Perri, D. et. al. (2006). Safety and Efficacy of Black Cohosh (Cimicifuga Racemosa) During Pregnancy and Lactation. The Canadian Journal of Clinical Pharmacology, 13 (3), 257-261.

Biletska Yana, PhD, Associate Professor, Department of International Ecommerce and Hotel and Restaurant Business, V. N. Karazin Kharkiv National University, Ukraine, e-mail: ya.belecka@karazin.ua, ORCID: http://orcid.org/0000-0001-8060-6579

Plotnikova Raisa, PhD, Associate Professor, Department of Food Technology, Kharkiv State University of Food Technology and Trade, Ukraine, e-mail: raisa1786@icloud.com, ORCID: http://orcid.org/ 0000-0003-4214-745X 